\title{
Haemolytic disease of the newborn and severe neonatal jaundice due to anti- Mur antibodies
}

\author{
*Visvalingam Arunath ${ }^{1}$, Mohamed Yaseen Nibras Mohammed ${ }^{1}$, Pathmanathan Sotheesan ${ }^{1}$, Vinushiya \\ Gunalini Quienters ${ }^{1}$, Anoma Weerawardena ${ }^{2}$, Nishani Lucas ${ }^{1,3}$
}

Sri Lanka Journal of Child Health, 2022; 51(1): 155-156

DOI: http://dx.doi.org/10.4038/sljch.v51i1.10027

(Key words: Haemolytic disease of newborn, Neonatal jaundice, Minor group red cell antibodies, Anti-Mur)

\begin{abstract}
Introduction
Maternal red cell antibodies are the commonest cause of Haemolytic Disease of Newborn (HDN). Although $\mathrm{Rh}$ and $\mathrm{ABO}$ antibodies are responsible for most cases, other minor red cell antibodies remain a significant but uncommon cause of $\mathrm{HDN}^{1}$. We report a Sri Lankan baby girl who developed HDN with severe neonatal jaundice due to anti-Mur, one of the minor group red cell antibodies.
\end{abstract}

\section{Case report}

A baby girl was born by elective lower segment caesarean section due to breech presentation at a gestational age of 37 weeks and 5 days. Birth weight was $4640 \mathrm{~g}$. She was the first live born of nonconsanguineous Sri Lankan parents. Mother had two previous first trimester miscarriages. The antenatal period was uneventful. Antenatal blood sugar screening in the mother did not reveal diabetes mellitus. Baby cried at birth and the Apgar scores were 10,10 and 10 at 1,5 and 10 minutes respectively. There was no family history of haemolytic anaemia. Neonatal examination was unremarkable

On day two of life, baby was found to have icterus up to the sole without pallor or organomegaly. Total serum bilirubin was $371 \mu \mathrm{mol} / \mathrm{L}$, which was just above the exchange transfusion level (phototherapy level: $270 \mu \mathrm{mol} / \mathrm{L}$, exchange transfusion level: 370 $\mu \mathrm{mol} / \mathrm{L}$, NICE guidelines $2010^{2}$ ), with an elevated

${ }^{1}$ Professorial Neonatology Unit, De Soysa Hospital for Women, Colombo 08, Sri Lanka

${ }^{2}$ Department of Haematology, De Soysa Hospital for Women, Colombo 08, Sri Lanka

${ }^{3}$ Department of Paediatrics, Faculty of Medicine, University of Colombo, Sri Lanka

*Correspondence: arunkarthi91@gmail.com

$$
\text { iD. }
$$

https//orcid.org/ 0000-0002-7705-0394

(Received on 29 March 2021: Accepted after revision on 21 May 2021)

The authors declare that there are no conflicts of interest

Personal funding was used for the project.

Open Access Article published under the Creative

Commons Attribution CC-BY (c) (i) License indirect fraction of $315.3 \mu \mathrm{mol} / \mathrm{L}$. Complete blood count showed a white cell count of $20,000 / \mathrm{cu} \mathrm{mm}$ (neutrophils $63 \%$, lymphocytes $32 \%$, monocytes $3 \%$ and eosinophils $2 \%$ ), a haemoglobin level of 11.5 $\mathrm{g} / \mathrm{dL}$, a platelet count of $262,000 / \mathrm{cu} \mathrm{mm}$ and a reticulocyte count of $14.8 \%$. Blood picture showed polychromatic red cells, nucleated red cells and occasional target cells, suggestive of haemolysis. Spherocytes, elliptocytes or fragmented red cells were not seen. C-reactive protein and hepatic transaminases were within normal limits. Blood culture was negative. Blood pictures of both parents were normal. Blood groups of mother and the baby were $\mathrm{O}$ positive and $\mathrm{O}$ negative respectively. Direct anti-globulin test (DAT) of the baby's blood was positive. Mother's direct and indirect antiglobulin tests were negative. Antibody screening of the mother revealed antibodies to Mur antigen, following which a diagnosis of HDN due to antiMur was made.

Baby was given double surface phototherapy (LED), after which the serum bilirubin came down to the phototherapy range at 6 hours after commencement of phototherapy. Serum bilirubin levels were meticulously monitored and phototherapy was given according to the 2010 NICE Guidelines². Single surface phototherapy was needed for a total of 7 days. Hydration was maintained using expressed breast milk in addition to direct breastfeeding. Mother was provided one to one support to establishing breastfeeding. Parental counselling was done regarding the risk of $\mathrm{HDN}$ in future pregnancies.

\section{Discussion}

Maternal red cell antibodies to $\mathrm{Rh}$ and $\mathrm{ABO}$ blood group systems are commonly responsible for the blood group incompatibilities in HDN., There are several other clinically significant red cell antibodies including MNS blood group system which can cause HDN. Antigens of the MNS blood group system are expressed in the red cell (RBC) membrane on two sialic acid-rich glycoproteins, glycophorin A (GPA) and glycophorin B (GPB). The MNS system is highly polymorphic and there are 46 distinct antigens, including $\mathrm{MUT}, \mathrm{Mi}^{\mathrm{a}}$ and Mur antigens ${ }^{1,3}$. 
Anti-Mur is a red cell antibody to a low-incidence antigen, that occurs in less than $1 \%$ of the population. It is known to cause HDN as well as transfusion reactions. Antenatal detection of these antibodies facilitates early detection of HDN and neonatal jaundice ${ }^{1,3,4}$. The homologous genes, $G Y P^{*} A$ and $G Y P^{*} B$ which are located on the long arm of chromosome 4 (4q31) encodes MNS blood group system ${ }^{1}$. The incidence of gene encoding Mur antigen is $5-6 \%$ in South East Asia ${ }^{3}$. Some South East Asian countries have included Mur positive RBCs in antibody screening tests ${ }^{3}$.

Anti-Mur antibodies are either IgG or $\operatorname{IgM}$ antibodies. Though, naturally occurring IgM antibodies are more frequent than IgG antibodies, IgG are more likely to be clinically significant as it crosses the placenta ${ }^{3,5}$. These antibodies are missed when using standard screening cells because transfusion laboratories in some developing countries use commercially available screening cells rather than prepared panels sourced from their own localities $^{3,4}$.

Clinically significant cases of hydrops fetalis and mild HDN due to anti-Mur have been reported ${ }^{7,8}$. In our patient, findings of significant neonatal indirect hyperbilirubinaemia and a strongly positive DAT with evidence of haemolysis were most likely due to anti-Mur detected in her mother's plasma. Genetic analysis for $G Y P^{*} A \& G Y P^{*} B$ genes would demonstrate the presence of the Mur antigen, although this facility was not available.

Screening for the presence of MNS antibodies is an important component in antenatal screening. The antibody screening test should be designed to ensure that all clinically significant antibodies among the local population are recognized so that steps can be taken to provide appropriate counselling and management to pregnant mothers at risk of HDN.

\section{References}

1. Lomas-Francis C. Miltenberger phenotypes are glycophorin variants: a review. ISBT Science Series 2011; 6(2): 296-301.

https://doi.org/10.1111/j.17512824.2011.0 1503.x

2. National Institute for Health and Care Excellence (NICE). Clinical guideline. Jaundice in newborn babies under 28 days. $9^{\text {th }}$ May 2010. Last updated in 26 October 2016. Available at: www.nice.org.uk/guidance/cg98 [accessed on $4 / 5 / 2021]$
3. Nadarajan V, Laing A, Saad S, Usin M. Prevalence and specificity of red-bloodcell antibodies in a multiethnic South and East Asian patient population and influence of using novel MUT+Mur+ kodecytes on its detection. Vox Sanguinis 2011; 102(1): 65-71.

https://doi.org/10.1111/j.14230410.2011.0 1507.x

PMid: 21592136

4. Poole J, Daniels G. Blood group antibodies and their significance in transfusion medicine. Transfusion Medicine Reviews 2007; 21(1): 58-71.

https://doi.org/10.1016/j.tmrv.2006.08.003 PMid: 17174221

5. Lo SC, Chang JS, Lin SW, et al.: Immunological characterization of anti- $\mathrm{Mi}$ (a), a red blood cell alloantibody, in Taiwan. Vox Sang 2002; 83:162-4. https://doi.org/10.1046/j.14230410.2002.0 0212.x

PMid: 12201846

6. Bakhtary S, Gikas A, Glader B, Andrews J. Anti-Mur as the most likely cause of mild haemolytic disease of the newborn. Transfusion 2016; 56(5):1182-4. https://doi.org/10.1111/trf.13552 PMid: 26996653

7. Wu K, Chang J, Lin M, Shih M, Lin H, Lee $\mathrm{C}$, et al. Hydrops fetalis caused by anti-Mur in first pregnancy - a case report. Transfusion Medicine 2002; 12(5): 325-7.. https://doi.org/10.1046/j.13653148.2002.0 0394.x

PMid: 12383339

8. Wu K, Chu S, Chang J, Shih M, Peng C. Haemolytic disease of the newborn due to maternal irregular antibodies in the Chinese population in Taiwan. Transfusion Medicine 2003; 13(5): 311-4. https://doi.org/10.1046/j.13653148.2003.0 0458.x

PMid: 14617342 